\author{
Abstracta Iranica \\ Abstracta Iranica Revue bibliographique pour le domaine irano-aryen \\ Volume 34-35-36 | 2017 \\ Comptes rendus des publications de 2011-2013
}

\title{
Florence Jullien. La Passion syriaque de Mar 'Abda. Quelques relations entre chrétiens et mazdéens
}

\author{
Marie-Jospeh Pierre
}

\section{(2) OpenEdition}

Journals

Édition électronique

URL : http://journals.openedition.org/abstractairanica/41928

DOI : 10.4000/abstractairanica.41928

ISSN : 1961-960X

Éditeur :

CNRS (UMR 7528 Mondes iraniens et indiens), Éditions de l'IFRI

Référence électronique

Marie-Jospeh Pierre, «Florence Jullien. La Passion syriaque de Mar 'Abda. Quelques relations entre chrétiens et mazdéens ", Abstracta Iranica [En ligne], Volume 34-35-36 | 2017, document 22, mis en ligne le 30 décembre 2016, consulté le 02 octobre 2020. URL : http://journals.openedition.org/

abstractairanica/41928; DOI : https://doi.org/10.4000/abstractairanica.41928

Ce document a été généré automatiquement le 2 octobre 2020.

Tous droits réservés 


\title{
Florence Jullien. La Passion syriaque de Mar 'Abda. Quelques relations entre chrétiens et mazdéens
}

\author{
Marie-Jospeh Pierre
}

\section{RÉFÉRENCE}

Florence Jullien. «La Passion syriaque de Mar 'Abda. Quelques relations entre chrétiens et mazdéens ", in : R. Gyselen et C. Jullien, éds., " Maître pour l'éternité ». Florilège offert à Ph. Gignoux pour son 80e anniversaire. Paris, AAEI - Peeters, 2011, p. 195-204. (St. Ir. Cahier 43)

1 En hommage aux travaux de Philippe Gignoux qui s'est si souvent intéressé aux relations entre chrétiens et mazdéens, cet article propose la traduction d'un texte syriaque, la Passion de Mār 'Abdā, évêque du Huzistān (le Bēth-Huzāyē), mis à mort avec quelques membres représentatifs de son clergé - véritable décapitation hiérarchique - à l'extrême fin du règne de Yazdgird I ${ }^{\text {er }}$ (399-420). Il s'agit de la première version française réalisée à ce jour de ce récit qui restitue le modèle hagiographique des tensions mazdéo-chrétiennes autour de la question de la destruction de pyrées.

\section{AUTEURS}

MARIE-JOSPEH PIERRE

Directrice d'Études honoraire, EPHE 